\title{
Bibliography of printed works
}

Acheson, E., A Gentry Community: Leicestershire in the Fifteenth Century, c. 1422-c. 1485, Cambridge, 1992.

Adams, N. and C. Donahue, Jun., eds, Select Cases from the Ecclesiastical Courts of the Province of Canterbury, c. 1200-1301, Selden Society, CXV, 1978-79.

Alexander, J. and P. Binski, eds, Age of Chivalry: Art in Plantagenet England, 12001400, London, 1987.

Altschul, M., A Baronial Family in Medieval England: the Clares, 1217-1314, Baltimore, 1965.

Amt, E., ed., Women's Lives in Medieval Europe: A Sourcebook, London, 1993.

Archer, R. E., 'Rich old ladies: the problem of late medieval dowagers', in A. Pollard, ed., Property and Politics: Essays in Later Medieval English History, Gloucester, 1984, pp. 15-35.

Archer, R. E., 'The estates and finances of Margaret of Brotherton, c. 1320-1399', Historical Research, LX, 1987, pp. 264-80.

Archer, R. E., "'How ladies ... who live on their manors ought to manage their households and estates": women as landholders and administrators in the later Middle Ages', in P. J. P. Goldberg, ed., Woman is a Worthy Wight: Women in English Society c. 1200-1500, Gloucester, 1992, chapter 6.

Archer, R. E. and B. E. Ferme, 'Testamentary procedure with special reference to the executrix', in Medieval Women in Southern England, Reading Medieval Studies, XV, 1989, pp. 3-34.

Armstrong, C. A. J., 'The piety of Cicely, duchess of York: a study in late medieval culture, in England, France and Burgundy in the Fifteenth Century, London, 1983, pp. 135-56.

Aston, M., “'Caim's castles": poverty, politics and disendowment', in Faith and Fire: Popular and Unpopular Religion 1350-1600, London, 1993, pp. 95-131.

Backhouse, J., Books of Hours, British Library, London, 1985.

Backhouse, J., The Luttrell Psalter, British Library, London, 1989.

Barber, R. and J. Barker, Tournaments: Jousts, Chivalry and Pageants in the Middle Ages, Woodbridge, 1989.

Bell, S. G., 'Medieval women book owners: arbiters of lay piety and ambassadors of culture', in M. Erler and M. Kowaleski, eds, Women and Power in the Middle Ages, Athens, 1988, pp. 149-87.

Blamires, A., ed., with K. Pratt and C. W. Marx, Woman Defamed and Woman Defended: An Anthology of Medieval Texts, Oxford, 1992.

Boffey, J., 'Women authors and women's literacy in fourteenth- and fifteenthcentury England', in C. M. Meale, ed., Women and Literature in Britain, 11501500, Cambridge, 1993, pp. 159-82.

Bourdillon, A. F. C., The Order of Minoresses in England, Manchester, 1926.

Brewer, J. S. and R. Howlett, eds, Monumenta Franciscana, 2 vols, Rolls Series, London, 1858-82. 
Britnell, R. H., 'Minor landlords in England and medieval agrarian capitalism', Past and Present, no. 89, 1980, pp. 3-22.

Brooke, C. N. L., The Medieval Idea of Marriage, Oxford, 1989.

Brundage, J. A., Law, Sex and Christian Society in Medieval Europe, Chicago, 1987.

Burgess, C., 'Late medieval wills and pious convention: testamentary evidence reconsidered', in M. Hicks, ed., Profit, Piety and the Professions in Later Medieval England, Gloucester, 1990, pp. 14-33.

Carpenter, C., Locality and Polity: A Study of Warwickshire Landed Society, 14011499, Cambridge, 1992.

Carpenter, D. A., 'Was there a crisis of the knightly class in the thirteenth century? The Oxfordshire evidence', English Historical Review, XCV, 1980, pp. $721-52$.

Catto, J., 'Religion and the English nobility in the later fourteenth century', in H. Lloyd-Jones, V. Pearl and B. Worden, eds, History and Imagination: Essays in honour of H. R. Trevor-Roper, London, 1981, pp. 43-55.

Chibnall, M., 'Women in Orderic Vitalis', Haskins Society Journal, II, 1990, pp. 105-21.

Clanchy, M. T., From Memory to Written Record: England 1066-1307, London, 1979.

Clarke, A., J. Caley, J. Bayley, F. Holbrooke and J. W. Clarke, eds, Rymer's Foedera, 1066-1383, 4 vols, Record Commission, London, 1816-69.

Cooke, K., 'Donors and daughters: Shaftesbury abbey's benefactors, endowments and nuns c. 1086-1130', in M. Chibnall, ed., Anglo-Norman Studies XII: Proceedings of the Battle Conference 1989, Woodbridge, 1990, pp. 29-45.

Coss, P. R., Lordship, Knighthood and Locality: A Study in English Society, c. 11801280, Past and Present Publications,Cambridge, 1991.

Coss, P. R., 'Sir Geoffrey de Langley and the crisis of the knightly class in thirteenth-century England', Past and Present, no. 68, 1975, pp. 3-37.

Coss, P. R., 'Bastard feudalism revised', Past and Present, no. 125, 1989, pp. 27-64.

Crawford, A., 'Victims of attainder: the Howard and de Vere women in the late fifteenth century', in Medieval Women in Southern England, Reading Medieval Studies, XV, 1989, pp. 59-74.

Crouch, D., William Marshal: Court, Career and Chivalry in the Angevin Empire 11471219, London, 1990.

Crouch, D., The Image of Aristocracy in Britain, 1000-1300, London, 1992.

Cullum, P. H., “And hir name was Charite”: charitable giving by and for women in late medieval Yorkshire', in P. J. P. Goldberg, ed., Woman is a Worthy Wight: Women in English Society c. 1200-1500, Gloucester, 1992, chapter 7.

Davies, R. R., 'Baronial accounts, incomes and arrears in the later Middle Ages', Economic History Review, second series, XXI, 1968, pp. 211-29.

Davis, N., ed., Paston Letters and Papers of the Fifteenth Century, 2 vols, Oxford, 1971-76.

Denholm-Young, N., Seignorial Administration in England, Oxford, 1937.

Denholm-Young, N., 'The Yorkshire estates of Isabella de Fortibus', Yorkshire Archaeological Journal, XXXI, 1934, pp. 388-420.

Douglas, D. C., William the Conqueror, London, 1964.

Douglas, D. C. and G. W. Greenaway, eds, English Historical Documents 1042-1189, London, 1953. 
Duby, G., trans. B. Bray, The Knight, the Lady and the Priest: The making of Modern Marriage in Medieval France, Harmondsworth, 1983.

Duffy, E., The Stripping of the Altars: Traditional Religion in England 1400-1580, New Haven, 1992.

Dugdale, W., Monasticon Anglicanum, J. Caley, H. Ellis and B. Bandinel, eds, 6 vols, London, 1817-30.

Dyer, C., Standards of Living in the Later Middle Ages: Social Change in England c. 1200-1520, Cambridge, 1989.

Erler, M. C., 'Three fifteenth-century vowesses', in C. M. Barron and A. F. Sutton, eds, Medieval London Widows 1300-1500, London, 1994, pp. 165-83.

Fairbank, F. R., 'The last earl of Warenne and Surrey and the distribution of his possessions', Torkshire Archaeological Journal, XIX, 1907, pp. 193-264.

Farley, A. and H. Ellis, eds, Liber Censualis vocatus Domesday Book, 4 vols, Record Commission, London, 1783-1816.

Furnivall, F. J., ed., The Fifty Earliest English Wills, Early English Text Society, original series, LXXVIII, 1882.

Gairdner, J., ed., The Paston Letters, 1422-1509, 4 vols, reprint of edition of 187275, Edinburgh, 1910.

Given-Wilson, C., The English Nobility in the Late Middle Ages: the FourteenthCentury Political Community, London, 1987.

Goldberg, P. J. P., Women, Work and Life Cycle in a Medieval Economy: Women in Tork and Torkshire, c. 1300-1520, Oxford, 1992.

Goodman, A., 'The countess and the rebels: Essex and a crisis in English society (1400)', Transactions of the Essex Archaeological Society, third series, II, 1970, pp. 267-79.

Gray, H. L., 'Incomes from land in England in 1436', English Historical Review, XLIX, 1934, pp. 607-39.

Greenway, D. E., ed., Charters of the Honour of Mowbray, 1107-91, British Academy, Records of Social and Economic History, new series, I, 1972.

Harding, A., England in the Thirteenth Century, Cambridge, 1993.

Hardy, T. D., ed., Rotuli Litterarum Clausarum in Turri Londinensi Asservati, 120427, 2 vols, Record Commission, London, 1833-44.

Hardy, T. D., ed., Rotuli de Oblatis et Finibus in Turri Londinensi Asservati, Tempore Regis Johannis, Record Commission, London, 1835.

Hardy, T. D., ed., Rotuli Litterarum Patentium in Turri Londinensi Asservati, 120116, Record Commission, London, 1835.

Hardy, T. D., ed., Rotuli Chartarum in Turri Londinensi Asservati, 1199-1216, Record Commission, London, 1837.

Harper-Bill, C., ed., The Cartulary of the Augustinian Friars of Clare, Suffolk Records Society, Suffolk Charters, XI, 1991.

Harper-Bill, C. and R. Mortimer, eds, Stoke by Clare Cartulary, 3 vols, Suffolk Records Society, Suffolk Charters, IV-VI, 1982-84.

Harvey, S., 'The knight and the knight's fee in England', Past and Present, no. 49, 1970, pp. 3-43, and reprinted in R. H. Hilton, ed., Peasants, Knights and Heretics, Cambridge, 1976, pp. 133-73.

Haskell, A. S., 'The Paston women on marriage in fifteenth-century England', Viator, IV, 1973, pp. 459-71. 
Helmholz, R. H., Marriage Litigation in Medieval England, Cambridge, 1974.

Hicks, M., 'Piety and lineage in the Wars of the Roses: the Hungerford experience', in R. A. Griffiths and J. Sherborne, eds, Kings and Nobles in the Later Middle Ages: A Tribute to Charles Ross, Gloucester, 1986, pp. 90-108.

Hicks, M., 'The piety of Margaret, Lady Hungerford (d. 1478)', Journal of Ecclesiastical History, XXXVIII, 1987, pp. 19-38.

Hicks, M., 'The last days of Elizabeth countess of Oxford', English Historical Review, CIII, 1988, pp. 76-95.

Holmes, G. A., The Estates of the Higher Nobility in Fourteenth-Century England, Cambridge, 1957.

Holmes, G. A., 'A Protest against the Despensers, 1326', Speculum, XXX, 1955, pp. 207-12.

Holt, J. C., Magna Carta, second edition, Cambridge, 1992.

Holt, J. C., 'Politics and property in early medieval England', Past and Present, no. 57, 1972, pp. 3-52.

Holt, J. C., 'Feudal society and the family in early medieval England: I. The revolution of 1066', Transactions of the Royal Historical Society, fifth series, XXXII, 1982, pp. 193-212.

Holt, J. C., 'Feudal society and the family in early medieval England: II. Notions of patrimony', Transactions of the Royal Historical Society, fifth series, XXXIII, 1983, pp. 193-220.

Holt, J. C., 'Feudal Society and the family in early medieval England: III. Patronage and politics', Transactions of the Royal Historical Society, fifth series, XXXIV, 1984, pp. 1-25.

Holt, J. C., 'Feudal society and the family in early medieval England: IV. The heiress and the alien', Transactions of the Royal Historical Society, fifth series, XXXV, 1985, pp. 1-28.

Hudson, J., Land, Law and Lordship in Anglo-Norman England, Oxford, 1994.

Hudson, J., 'Life-grants of land and the development of inheritance in AngloNorman England', in M. Chibnall, ed., Anglo-Norman Studies, XII: Proceedings of the Battle Conference, 1989, Woodbridge, 1990, pp. 67-80.

Illingworth, W. and J. Caley, eds, Placita de Quo Warranto, Record Commission, London, 1818.

Jenkinson, H., 'Mary de Sancto Paulo, foundress of Pembroke College, Cambridge', Archaeologia, LXXXVI, 1915, pp. 401-46.

Jones, M. K. and M. G. Underwood, The King's Mother: Lady Margaret Beaufort, Countess of Richmond and Derby, Cambridge, 1992.

Kingsford, C. L., ed., The Stonor Letters and Papers, 1290-1483, 2 vols, Camden Society, third series, XXIX, XXX, 1919.

Knowles, C. H., 'Provision for the families of the Montfortians disinherited after the battle of Evesham', in P. R. Coss and S. D. Lloyd, eds, Thirteenth Century England I: Proceedings of the Newcastle upon Tyne Conference, 1985, Woodbridge, 1986, pp. 124-7.

Knowles, D., The Monastic Order in England, Cambridge, 1950.

Knowles, D. and R. N. Hadcock, Medieval Religious Houses, England and Wales, London, 1971.

Labarge, M. W., A Baronial Household of the Thirteenth Century, London, 1965. 
Labarge, M. W., Women in Medieval Life, London, 1986.

Lamond, E., ed., Walter of Henley's Husbandry, Royal Historical Society, London, 1890.

Lander, J. R., 'Attainder and forfeiture, 1453-1509', Historical Journal, IV, 196 1, pp. 119-51.

Lander, J. R., 'Marriage and politics in the fifteenth century: the Nevilles and the Wydevilles', Bulletin of the Institute of Historical Research, XXXVI, 1963, pp. 119-52.

Le Goff, J., The Birth of Purgatory, Aldershot, 1984.

Lloyd, S., English Society and the Crusade, 1216-1307, Oxford, 1988.

Loengard, J. S., "Of the gift of her husband": English dower and its consequences in the year 1200', in J. Kirshner and S. F. Wemple, eds, Women of the Medieval World, Oxford, 1985, pp. 215-55.

Loyd, L. C. and D. M. Stenton, eds, Sir Christopher Hatton's Book of Seals, Oxford, 1950.

Luard, H. R., ed., Annales Monastici, 5 vols, Rolls Series, London, 1864-69.

Lucas, A. M., Women in the Middle Ages: Religion, Marriage and Letters, Brighton, 1983.

Lyte, H. C. M., A History of Dunster, 2 vols, London, 1909.

McFarlane, K. B., Lancastrian Kings and Lollard Knights, Oxford, 1972.

McFarlane, K. B., The Nobility of Later Medieval England, Oxford,1973.

Macray, W. D., ed., Chronicon Abbatiae Rameseiensis, Rolls Series, London, 1886.

Maddicott, J. R., Law and Lordship: Royal Justices as Retainers in Thirteenth-and Fourteenth-Century England, Past and Present supplement, no. 4, 1978.

Maitland, F. W., ed., Bracton's Note Book, 3 vols, London, 1887.

Malory, Sir Thomas, edited by J. Cowen, Le Morte D'Arthur, 2 vols, Harmondsworth, 1986.

Martin, C. T., ed., Registrum Epistolarum Johannis Peckham, Archiepiscopi Cantuariensis, 3 vols, Rolls Series, London, 1882-86.

Mason, E., ed., The Beauchamp Cartulary: Charters 1100-1268, Pipe Roll Society, new series, XLIII, 1980.

Mate, M., 'Profit and productivity on the estates of Isabella de Forz, 1260-92', Economic History Review, second series, XXXIII, 1980, pp. 326-34.

Meale, C. M., “.... alle the bokes that I haue of latyn, englisch and frensch": laywomen and their books in late medieval England', in C. M. Meale, ed., Women and Literature in Britain, 1150-1500, Cambridge, 1993, pp. 128-58.

Mertes, K., The English Noble Household, 1250-1600: Good Governance and Politic Rule, Oxford, 1988.

Miller, E. and J. Hatcher, Medieval England - Rural Society and Economic Change 1086-1348, London, 1978.

Millett, B., 'Women in No Man's Land: English recluses and the development of vernacular literature in the twelfth and thirteenth centuries', in C. M. Meale, ed., Women and Literature in Britain, 1150-1500, Cambridge, 1993, pp. 86-103.

Milsom, S. F. C., 'Inheritance by women in the twelfth and early thirteenth centuries', in M. S. Arnold, T. A. Green, S. A. Scully and S. D. White, On the Laws and Customs of England: Essays in honor of Samuel E. Thorne, Chapel Hill, 1981, pp. 60-89. 
Morgan, D. A. L., 'The individual style of the English gentleman', in M. Jones, ed., Gentry and Lesser Nobility in Late Medieval Europe, Gloucester, 1986, pp. 15-35.

Newton, S. M., Fashion in the Age of the Black Prince: A Study of the Years 1340-1365, Woodbridge, 1980.

Nichols, J., A Collection of All the Wills of the Kings and Queens of England, London, 1780 .

Nichols, J. G. and J. Bruce, eds, Wills from Doctors' Commons: A Selection from the Wills of Eminent Persons proved in the Prerogative Court of Canterbury, 1495-1695, Camden Society, old series, LXXXIII, 1863.

Orme, N., From Childhood to Chivalry: The Education of the English Kings and Aristocracy 1066-1530, London, 1984.

Palgrave, F., ed., Rotuli Curiae Regis, 6 Richard I - 1 John, 2 vols, Record Commission, London, 1835.

Palmer, R. C., 'Contexts of marriage in medieval England: evidence from the king's court circa 1300', Speculum, LIX, 1984, pp. 42-67.

Patterson, R. B., ed., Earldom of Gloucester Charters: The Charters and Scribes of the Earls and Countesses of Gloucester to ad 1217, Oxford, 1973.

Payling, S., Political Society in Lancastrian England: The Greater Gentry of Nottinghamshire, Oxford, 1991.

Pisan, Christine de, trans. S. Lawson, The Treasure of the City of Ladies or The Book of the Three Virtues, Harmondsworth, 1985.

Plucknett, T. F. T., A Concise History of the Common Law, fourth edition, London, 1948.

Plucknett, T. F. T., Legislation of Edward I, Oxford, 1949.

Pollard, A., 'Estate management in the later Middle Ages: the Talbots and Whitchurch, 1383-1525', Economic History Review, second series, XXV, 1972, pp. 553-66.

Pollock, F. and F. W. Maitland, The History of English Law before the time of Edward I, 2 vols, second edition, Cambridge, 1898.

Power, E., Medieval English Nunneries c. 1275-1535, Cambridge, 1922.

Powicke, F. M., King Henry III and the Lord Edward, 2 vols, Oxford, 1947.

Pugh, T. B. and C. D. Ross, 'The English baronage and the income tax of 1436', Bulletin of the Institute of Historical Research, XXVI, 1953, pp. 1-28.

Raban, S., Mortmain Legislation and the English Church, 1279-1500, Cambridge, 1982.

Rawcliffe, C., The Staffords, earls of Stafford and dukes of Buckingham, 1394-1521, Cambridge, 1978.

Richmond, C., The Paston Family in the Fifteenth Century: The First Phase, Cambridge, 1990.

Richmond, C., 'Religion and the fifteenth-century gentleman', in R. B. Dobson, ed., The Church, Politics and Patronage in the Fifteenth Century, Gloucester, 1984, pp. 193-208.

Richmond, C., 'The Pastons revisited: marriage and the family in fifteenth-century England', Bulletin of the Institute of Historical Research, LVIII, 1985, pp. 25-36.

Richmond, C., 'Thomas Lord Morley (d. 1416) and the Morleys of Hingham', Norfolk Archaeology, XXXIX, 1984-86, pp. 1-12.

Riley, H. T., ed., Thomae Walsingham Historia Anglicana, 2 vols, Rolls Series, London, 1863-64. 
Riley, H. T,. ed., Johannis de Trokelowe et Henrici de Blaneford Chronica et Annales, Rolls Series, London, 1865.

Roberts, C., ed., Excerpta e Rotulis Finium in Turri Londinensi Asservatis, Henry III, 1216-72, 2 vols, Record Commission, London, 1835-36.

Rogers, K. H., ed., Lacock Abbey Charters, Wiltshire Record Society, XXXIV, 1979.

Rose, G. and W. Illingworth, eds, Placitorum in Domo Capitulari Westmonasteriensi Asservatorum Abbreviatio, Record Commission, London, 1811.

Rosenthal, J. T., The Purchase of Paradise: Gift Giving and the Aristocracy, 13071485, London, 1972.

Rosenthal, J. T., 'Aristocratic marriage and the English peerage, 1350-1500: social institution and personal bond', Journal of Medieval History, X, 1984, pp. 181-94.

Ross, C. D., 'The household accounts of Elizabeth Berkeley, countess of Warwick, 1420-1', Transactions of the Bristol and Gloucestershire Archaeological Society, LXX, 1951, pp. 81-105.

Ross, C. D., 'Forfeiture for treason in the reign of Richard II', English Historical Review, LXXI, 1956, pp. 560-75.

Ross, C. D. and T. B. Pugh, 'Materials for the study of baronial incomes in fifteenth-century England', Economic History Review, second series, VI, 195354, pp. 185-94.

Rothwell, H., ed., English Historical Documents 1189-1327, London, 1975.

Round, J. H., ed., Rotuli de Dominabus et Pueris et Puellis de XII Comitatibus (1185), Pipe Roll Society, XXXV, 1913.

Rubin, M., Corpus Christi: The Eucharist in Late Medieval Culture, Cambridge, 1991.

Salu, M. B., trans., The Ancrene Riwle, Exeter Medieval English Texts and Studies, Exeter, 1990.

Sanders, I. J., English baronies: A Study of their Origin and Descent, 1086-1327, Oxford, 1960.

Saul, N., Knights and Esquires: the Gloucestershire Gentry in the Fourteenth Century, Oxford, 1981.

Saul, N., Scenes from Provincial Life: Knightly Families in Sussex, 1280-1400, Oxford, 1986.

Scattergood, V. J. and J. W. Sherborne, eds, English Court Culture in the Later Middle Ages, London, 1983.

Shahar, S., The Fourth Estate: A History of Women in the Middle Ages, London, 1983.

Shahar, S., Childhood in the Middle Ages, London, 1990.

Sheehan, M. M., 'The influence of canon law on the property rights of married women in England', Mediaeval Studies, XXV, 1963, pp. 109-24.

Sheehan, M. M., 'Choice of marriage partner in the Middle Ages: development and mode of application of a theory of marriage', Studies in Medieval and Renaissance History, new series, I, 1978, pp. 1-33.

Sheehan, M. M., 'Marriage theory and practice in the conciliar legislation and diocesan statutes of medieval England', Mediaeval Studies, XL, 1978, pp. 40860 .

Simpson, A. W. B., An Introduction to the History of the Land Law, Oxford, 1961.

Sir Gawain and the Green Knight, trans. B. Stone, second edition, Harmondsworth, 1974. 
Stafford, P., 'Women in Domesday', in Medieval Women in Southern England, Reading Medieval Studies, XV, 1989, pp. 75-94.

Stapleton, T., ed., Plumpton Correspondence, Camden Society, old series, IV, 1839.

Stenton, F. M., The First Century of English Feudalism, second edition, Oxford, 1961.

Stenton, F. M., ed., Facsimiles of Early Charters from Northamptonshire Collections, Northamptonshire Record Society, IV, 1927.

Stubbs, W., ed., Gesta Regis Henrici Secundi Benedicti Abbatis, 2 vols, Rolls Series, London, 1867.

Swanson, J., 'Childhood and childrearing in ad status sermons by later thirteenthcentury friars', Journal of Medieval History, XVI, 1990, pp. 309-31.

Swanson, R. N., Church and Society in Late Medieval England, Oxford, 1989.

Swanson, R. N., ed., Catholic England: Faith, Religion and Observance before the Reformation, Manchester, 1993.

Thompson, S., Women Religious: The Founding of English Nunneries after the Norman Conquest, Oxford, 1991.

Turner, R. V., 'The Mandeville inheritance, 1189-1236: its legal, political and social context', Haskins Society Journal, I, 1989, pp. 147-72.

Tyerman, C., England and the Crusades, 1095-1588, Chicago, 1988.

Vale, M. G. A., Piety, Charity and Literacy among the Yorkshire Gentry, 1370-1480, Borthwick Papers, no. 50, York, 1976.

Veale, E. M., The English Fur Trade in the Later Middle Ages, Oxford, 1966.

Walker, D., 'Miles of Gloucester, earl of Hereford', Transactions of the Bristol and Gloucestershire Archaeological Society, LXXVII, 1958, pp. 66-84.

Walker, S. S., 'Proof of age of feudal heirs in medieval England', Mediaeval Studies, XXXV, 1973, pp. 306-23.

Ward, J. C., English Noblewomen in the Later Middle Ages, London, 1992.

Ward, J. C., 'Fashions in monastic endowment: the foundations of the Clare family, 1066-1314', Journal of Ecclesiastical History, XXXII, 1981, pp. 427-51.

Ward, J. C., 'The place of the honour in twelfth-century society: the honour of Clare 1066-1217', Proceedings of the Suffolk Institute of Archaeology and History, XXXV, 1983, pp. 191-202.

Ward, J. C., 'Royal service and reward: the Clare family and the Crown, 10661154', in R. A. Brown, ed., Anglo-Norman Studies XI: Proceedings of the Battle Conference 1988, Woodbridge, 1989, pp.261-78.

Ward, J. C., 'Sir John de Coggeshale: an Essex knight of the fourteenth century', Essex Archaeology and History, XXII, 1991, pp. 61-6.

Ward, J. C., 'Elizabeth de Burgh, Lady of Clare (d. 1360)', in C. M. Barron and A. F. Sutton, eds, Medieval London Widows 1300-1500, London, 1994, pp. 29-45.

Waugh, S. L., 'Marriage, class and royal lordship in England under Henry III', Viator, XVI, 1985, pp. 181-207.

Waugh, S. L., 'Tenure to contract: lordship and clientage in thirteenth-century England', English Historical Review, CI, 1986, pp. 811-39.

Wentersdorf, K. P., 'The clandestine marriages of the Fair Maid of Kent', Journal of Medieval History, V, 1979, pp. 203-31.

Wood-Legh, K. L., Perpetual Chantries in Britain, Cambridge, 1965. 
Woolgar, C. M., ed., Household Accounts from Medieval England, 2 vols, British Academy, Records of Social and Economic History, new series, XVII, XVIII, Oxford, 1992-93.

Wright, S. M., The Derbyshire Gentry of the Fifteenth Century, Derbyshire Record Society, VIII, 1983. 